\title{
Conventional surgery results in patients originally referred for transcatheter aortic valve implantation
}

\author{
G Rescigno $^{*}$, T Piva $^{3}$, I Mazzanti ${ }^{2}$, C Aratari ${ }^{1}$, G Pupita ${ }^{2}$, A D'Alfonso ${ }^{1}$, A Capucci ${ }^{2}$, GP Perna ${ }^{4}$, L Torracca $^{1}$ \\ From 23rd World Congress of the World Society of Cardio-Thoracic Surgeons \\ Split, Croatia. 12-15 September 2013
}

\section{Background}

Transcatheter aortic valve implantation (TAVI) is increasingly considered as a viable alternative to conventional aortic valve replacement (AVR) in high-risk patients. However, long term results are still scarce and medical community hesitates in enlarging indications to lower risk subjects. Moreover, available devices are expensive and a strict potential candidate selection is necessary.

\section{Methods}

From April 2008 to August 2012, 212 patients, originally referred for percutaneous treatment, were thoroughly evaluated by the Aortic Team of our Department in order to choose the optimal procedure. Of them 55 patients (35 F;20 M) were considered as still acceptable candidates for conventional AVR.

\section{Results}

Mean age was $80.7 \pm 4.7$ years, mean additive and logistic Euroscore 1 were $9.7 \pm 1.8$ and $17.8 \% \pm 9.5$, respectively. Mean Euroscore II was $7.9 \% \pm 5.5$. Mean NYHA class was $2.9 \pm 0.5$. The majority of patients $(87.2 \%)$ presented a geriatric frailty score of $0-1$. Four patients showed a heavily calcified ascending aorta and 5 patients (9\%) were reoperations. Hospital mortality was $10.9 \%$ (6 pts). Mean followup was $535.9 \pm 407.4$ days (range: 6-1365 days). Six other patients died during this period for a mean survival of $74.4 \% \pm 6.9$ at 2 years. Mean NYHA class at 1 year was $1.25 \pm 0.5$ ( $\mathrm{p}<0.01$ vs preoperative value).

* Correspondence: grescigno@me.com

'Departments of Cardiac Surgery, Ospedali Riuniti di Ancona, Ancona, Italy

Full list of author information is available at the end of the article

\section{Conclusion}

AVR should be indicated with caution in high-risk patients originally referred for TAVI. Despite medium term results are good, with excellent functional status, hospital mortality is not negligible.

\section{Authors' details \\ 'Departments of Cardiac Surgery, Ospedali Riuniti di Ancona, Ancona, Italy. ${ }^{2}$ Academic Cardiology, Ospedali Riuniti di Ancona, Ancona, Italy. \\ ${ }^{3}$ Interventional Cardiology, Ospedali Riuniti di Ancona, Ancona, Italy. \\ ${ }^{4}$ Cardiology, Ospedali Riuniti di Ancona, Ancona, Italy.}

Published: 11 September 2013

doi:10.1186/1749-8090-8-S1-047

Cite this article as: Rescigno et al:: Conventional surgery results in patients originally referred for transcatheter aortic valve implantation. Journal of Cardiothoracic Surgery 2013 8(Suppl 1):047.

Submit your next manuscript to BioMed Central and take full advantage of:

- Convenient online submission

- Thorough peer review

- No space constraints or color figure charges

- Immediate publication on acceptance

- Inclusion in PubMed, CAS, Scopus and Google Scholar

- Research which is freely available for redistribution

Submit your manuscript at www.biomedcentral.com/submit
( Biomed Central 